\title{
Soil and water bioengineering: Practice and research needs for reconciling natural hazard control and ecological restoration
}

\author{
F. Rey ${ }^{\mathrm{a}, *}$, C. Bifulco ${ }^{\mathrm{b}}$, G.B. Bischetti ${ }^{\mathrm{c}}$, F. Bourrier ${ }^{\mathrm{a}}$, G. De Cesare ${ }^{\mathrm{d}}$, F. Florineth ${ }^{\mathrm{e}}$, F. Graf ${ }^{\mathrm{f}}$, M. Marden ${ }^{\mathrm{g}}$, \\ S.B. Mickovski ${ }^{\mathrm{h}}$, C. Phillips ${ }^{\mathrm{i}}$, K. Peklo ${ }^{\mathrm{j}}$, J. Poesen ${ }^{\mathrm{k}}$, D. Polster ${ }^{1}$, F. Preti ${ }^{\mathrm{m}}$, H.P. Rauch ${ }^{\mathrm{f}}$, P. Raymond ${ }^{\mathrm{n}}$, P. Sangalli ${ }^{\circ}$, \\ G. Tardio $^{\mathrm{p}}$, A. Stokes ${ }^{\mathrm{q}}$ \\ a Univ. Grenoble Alpes, Irstea, UR LESSEM, 2 rue de la Papeterie, BP 76, 38402 Saint-Martin-d'Hères, France \\ ${ }^{\mathrm{b}}$ Universidade de Lisboa, Instituto Superior de Agronomia, Centro de Ecologia Aplicada Prof. Baeta Neves, Lisboa, Portugal \\ ${ }^{c}$ Department of Agricultural and Environmental Science, Università degli Studi di Milano, Milan, Italy \\ d Laboratory of Hydraulic Constructions LCH, École Polytechnique Fédérale de Lausanne EPFL, Station 18, CH-1015 Lausanne, Switzerland \\ e Institute of Soil Bioengineering and Landscape Construction, Department of Civil Engineering and Natural Hazards, University of Natural Resources and Life Sciences, Vienna, Austria \\ ${ }^{\mathrm{f}}$ WSL Institute for Snow and Avalanche Research SLF, Flüelastrasse 11, CH-7260 Davos Dorf, Switzerland \\ g Landcare Research, PO Box 445, Gisborne 4040, New Zealand \\ h School of Engineering and Built Environment, Glasgow Caledonian University, 70 Cowcaddens Rd, Glasgow G4 0BA, Scotland, UK \\ ${ }^{\mathrm{i}}$ Landcare Research, PO Box 69040, Lincoln 7640, New Zealand \\ j I.C.E. Klaus PEKLO, Soil and Fluvial Bioengineering Consultancy SARL, Lasmarios, 82160, Parisot, France \\ ${ }^{\mathrm{k}}$ Department of Earth and Environmental Sciences, KU Leuven, Celestijnenlaan 200E, B-3001 Heverlee, Belgium \\ ${ }^{1}$ Polster Environmental Services, 6015 Mary Street, Duncan, BC V9L 2G5, Canada \\ ${ }^{\mathrm{m}}$ University Firenze - GESAAF, Engineering for Agro-Forestry and Biosystems Division, WaVe Research Unit, via san Bonaventura 13, 50145 Firenze, Italy \\ n Terra Erosion Control Ltd., 308 Hart Street, Nelson, British Columbia V1L5N5, Canada \\ - Sangalli Coronel y AsociadosSL, Bioingeniería y Paisaje Montesol, 24-20016 San Sebastian, Spain \\ p Technical University of Madrid, Avenida Niceto Alcalá Zamora 6 4D, Getafe, Madrid 28905, Spain \\ q INRA, AMAP, CNRS, IRD, University Montpellier, CIRAD, Montpellier, France
}

\section{H I G H L I G H T S}

- Soil and water bioengineering is an ecological engineering solution providing several benefits to both humans and nature.

- There is an emphasis on the necessity to reconcile both natural hazard control and ecological restoration.

- Applied research in geosciences and ecology can be used in an interactive process with practitioners to reach this aim.

- Sound soil and water bioengineering methods that reconcile both objectives are proposed.

\section{A R T I C L E I N F O}

\section{Article history:}

Received 22 June 2018

Received in revised form 16 August 2018

Accepted 17 August 2018

Available online 18 August 2018

Editor: Jay Gan

\section{Keywords:}

Benefits

Biodiversity

\begin{abstract}
A B S T R A C T
Soil and water bioengineering is a technology that encourages scientists and practitioners to combine their knowledge and skills in the management of ecosystems with a common goal to maximize benefits to both man and the natural environment. It involves techniques that use plants as living building materials, for: (i) natural hazard control (e.g., soil erosion, torrential floods and landslides) and (ii) ecological restoration or nature-based re-introduction of species on degraded lands, river embankments, and disturbed environments. For a bioengineering project to be successful, engineers are required to highlight all the potential benefits and ecosystem services by documenting the technical, ecological, economic and social values. The novel approaches used by bioengineers raise questions for researchers and necessitate innovation from practitioners to design bioengineering concepts and techniques. Our objective in this paper, therefore, is to highlight the practice and research needs in soil and water bioengineering for reconciling natural hazard control and ecological restoration. Firstly, we review the definition and development of bioengineering technology,
\end{abstract}

* Corresponding author at: Univ. Grenoble Alpes, Irstea, UR LESSEM, 2 rue de la Papeterie, BP 76, 38402 Saint-Martin-d'Hères, France.

E-mail addresses: freddy.rey@irstea.fr (F. Rey), bischetti@unimi.it (G.B. Bischetti), franck.bourrier@irstea.fr (F. Bourrier), giovanni.decesare@epfl.ch (G. De Cesare), florin.florineth@boku.ac.at (F. Florineth), graf@slf.ch (F. Graf), mardenm@landcareresearch.co.nz (M. Marden), slobodan.mickovski@gcu.ac.uk (S.B. Mickovski),

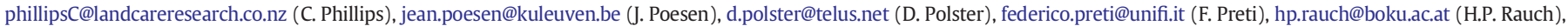
pierre@terraerosion.com (P. Raymond), sangalli@sangallipaisaje.com (P. Sangalli), alexia.stokes@cirad.fr (A. Stokes). 
Ecological engineering Ecosystem services Erosion

Vegetation while stressing issues concerning the design, implementation, and monitoring of bioengineering actions. Secondly, we highlight the need to reconcile natural hazard control and ecological restoration by posing novel practice and research questions.

\section{Development and issues in soil and water bioengineering}

1.1. Definition, applications and benefits of soil and water bioengineering

Soil and water bioengineering combines the implementation of techniques using plants as living building materials, through knowledge of their mechanical and/or biological properties (Fig. 1) (Barker et al.,
2004; Stokes et al., 2004). Bioengineering is a well-recognized component of ecological engineering, itself defined as "the design of sustainable systems, consistent with ecological principles, which integrate human society with its natural environment for the benefit of both" (Mitsch and Jørgensen, 2003; Mitsch, 2012). Bioengineering is used to: (i) control natural hazards (e.g., Norris et al., 2008; Dhital et al., 2013), (ii) restore or reintroduce plant and animal species onto
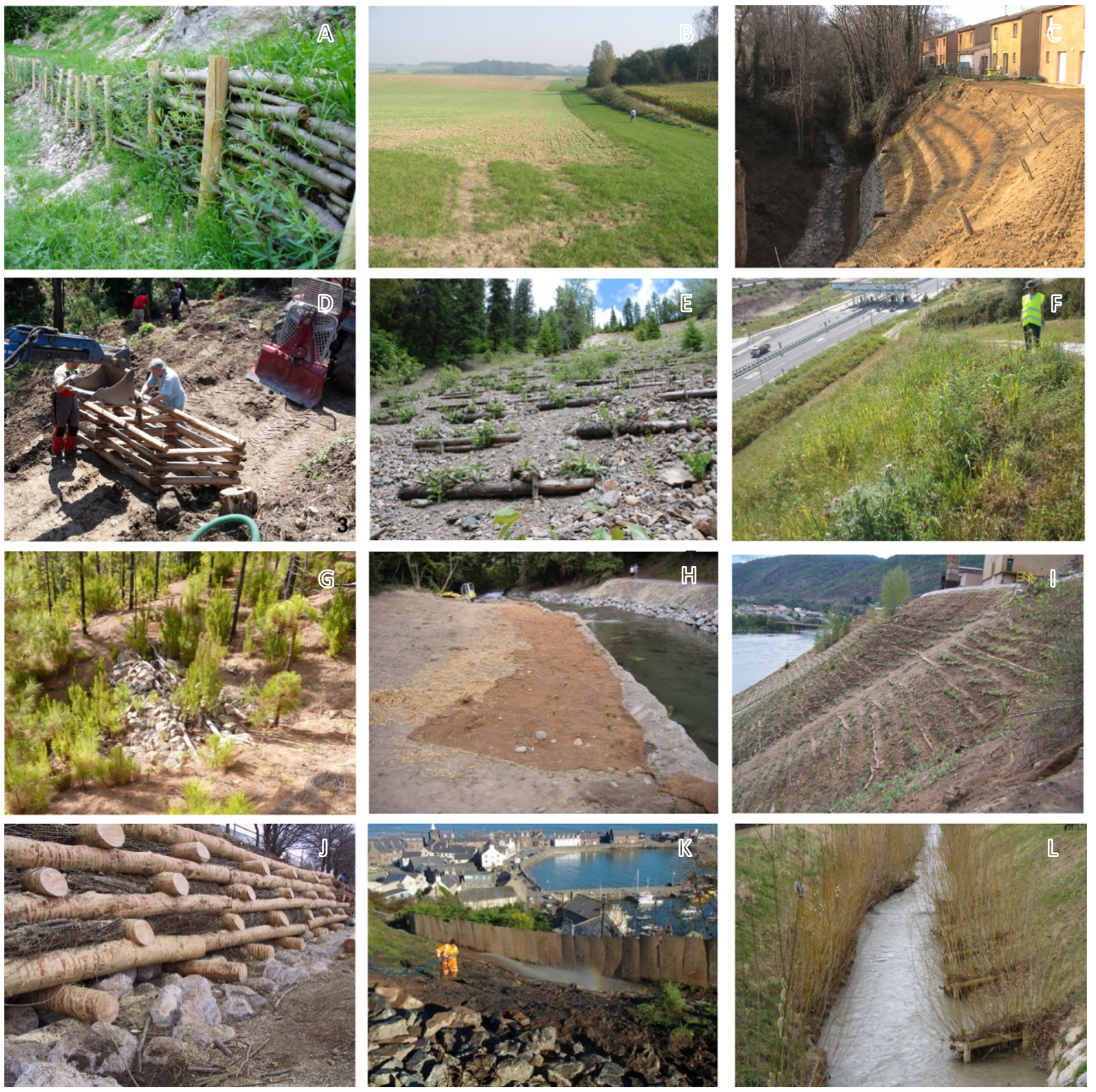

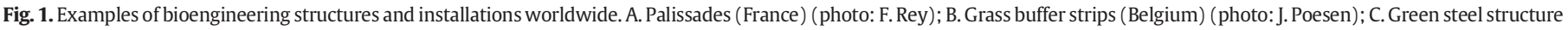

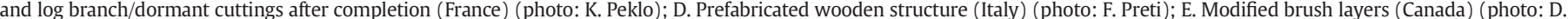

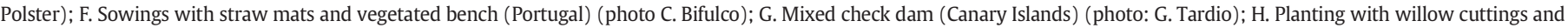

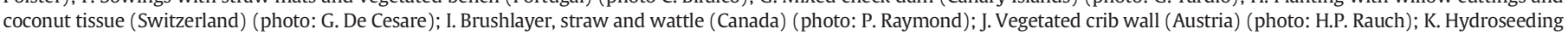
(Scotland) (photo: S. Mickovski); L. River modeling (Austria) (photo: F. Florineth). 
degraded lands and disturbed environments (e.g., Li et al., 2006; Rauch et al., 2014), and (iii) increase soil, air and water quality (e.g., Pretty et al., 2003; Woolsey et al., 2007).

Natural hazards such as soil erosion, torrential floods, and landslides, are phenomena that have severe consequences globally (Poesen et al., 2003; Smith and Katz, 2013; Poesen, 2017). The use of vegetation for protecting against natural hazards and attaining economic and/or social goals is typical of traditional forest and hydraulic engineering programs in Europe, such as the 'Restauration des terrains en montagne' (RTM) in France (Vallauri et al., 2002), 'Wildbach und Lawinen Verbauung' (WLV) in Germany and Austria, or 'Sistemazioni Idraulico-Forestali' (SIF) in Italy (Bresci and Preti, 2010; Bischetti et al., 2014). Today, the control of these types of hazards using herbaceous and woody vegetation through bioengineering remains a major challenge in areas where technical, socioeconomic, and ecological issues are confounding factors that can hinder success (Phillips et al., 2013; Dhital and Tang, 2015). Bioengineering in areas that are difficult to access, e.g. torrential catchments, riverbanks and lakes, as well as on disturbed lands, such as agricultural zones, road and rail embankments, ski slopes, mines, quarries and in urban areas (Lin et al., 2006), requires understanding of the interdependency of hydrological, ecological, and biophysical processes underway at the site. Bioengineering solutions should provide a combination of the benefits of immediate hazard control, comprising techniques such as (Fig. 1): (i) brush layers (that provide deep-seated protection), (ii) drain fascines or live pole drains (which drain excess water to allow vegetation establishment), (iii) vegetated crib walls (that immediately protect stream banks), (iv) brush mattresses (providing roughness from establishment against flow), and the long-term stabilization due to plant reinforcement effects. As with any stabilization technique, there is a stress (or load) transfer between the soil and the structure, but, in contrast to other solutions, this initial response is modified by the evolving role of the living material used in the bioengineering structure (Preti and Giadrossich, 2009; Graf and Frei, 2013; Yildiz et al., 2015, 2018; Tardio and Mickovski, 2016). This latter feature must be reflected in the bioengineering work design methodologies.

Ecological restoration encompasses all actions for repairing degraded lands, with the aim of reestablishing both form and function to attain autonomous and stable ecosystems (Clewell and Aronson, 2013). Ecological engineering in general and bioengineering in particular, can be employed for the restoration of a degraded environment (Mitsch and Jørgensen, 2004). Actions can include: (i) rehabilitating degraded land, which requires techniques aimed at recovering the natural succession of the ecosystem, especially by installing pioneer vegetation and enhancing its development; and (ii) monitoring and maintaining the rehabilitated land, thereby guiding the natural dynamics of the degraded systems so that they recover with a structural and functional autonomy (Aronson et al., 1993). A significant advantage of bioengineering actions is the incorporation of vegetation establishment and succession processes into the design stage. Therefore, the need for further intervention or maintenance is reduced and a long-term solution is provided. Bioengineering could also make restoration faster in the sense that, if the path of plant succession is known, it is possible to establish vegetation at the most advanced stage which will be compatible with the soil and microclimatic conditions of the site. Moreover, considering the energy balance of any civil engineering construction, a benefit from using soil bioengineering techniques is that although we need energy for its construction, we "save" energy with the development of the plant biomass. Finally these actions not only include ecological restoration, but also water and soil quality restoration or depollution (e.g., Wang et al., 2008).

Soil and water bioengineering is an emerging discipline globally, with regulatory frameworks (including the European Water Framework Directive or more recently the European Green Infrastructure Strategy) introducing the need to implement "soft" techniques for natural hazard control instead of "hard" techniques (engineered concrete and steel structures such as check dams), in the pursuit of restoring degraded environments or preventing further degradation during new construction. Prioritizing soil and water bioengineering techniques is now highly encouraged in the European Community and in many countries worldwide, often promoted through various incentives (e.g., European Commission, 2013). The International Union for the Conservation of Nature (IUCN) is proactively endorsing the use of Nature-based solutions for disaster risk reduction (EcoDRR), and includes soil bioengineering as a technique for protecting against natural hazards (Furuta et al., 2016; Renaud et al., 2016). Questioning practitioners and scientists about their experience, successes, and failures will allow a better understanding of the multiple benefits and services that natural habitats and human populations derive from bioengineering actions (Table 1).

\subsection{An interactive process between researchers and practitioners}

Soil and water bioengineering implies an interface between the researcher and the practitioner, i.e. between the improved knowledge base and its application (Stokes et al., 2013, 2014; Mitsch, 2014). The questions raised are increasingly complex and many practitioners are now involved in research projects, improving dialogue and mediation between different stakeholders. Bioengineering projects could also benefit from more multi- and inter-disciplinary approaches, as well as from a better understanding of practical issues experienced by practitioners (e.g., choice of materials, costs, insurance, health and safety, and management of human resources).

\section{Table 1}

Illustration of some ecosystem services provided by grass buffer strips, grassed waterways, and small flood retention ponds (bioengineering techniques) installed to reduce soil erosion rates by water and muddy floods in the loess belt of Belgium (based on Vandaele (2010) and various unpublished data).

\begin{tabular}{|c|c|}
\hline Ecosystem services & Illustrations or details \\
\hline $\begin{array}{l}\text { Maintenance and improvement } \\
\text { of soil ecosystem services }\end{array}$ & $\begin{array}{l}\text { e.g. Food, fiber, fuel and other biomass } \\
\text { production; environmental interactions such as } \\
\text { water filtering, carbon storage (e.g., due to the } \\
\text { change of cropland to grassland) and nutrient } \\
\text { cycling (e.g. N and P), transformation of } \\
\text { substances, biological habitat for soil micro-- } \\
\text { organisms, fauna and gene pool; archive of our } \\
\text { past (artefacts and indicators of environmental } \\
\text { change) }\end{array}$ \\
\hline $\begin{array}{l}\text { Maintenance and improvement } \\
\text { of hydrological systems }\end{array}$ & $\begin{array}{l}\text { e.g. On site water infiltration, retention and } \\
\text { storage, flow energy dissipation, off site flood } \\
\text { control through reduced peak flow discharge } \\
\text { and reduced sediment overloads }\end{array}$ \\
\hline Increase of biodiversity & $\begin{array}{l}\text { e.g. Vegetation (such as properly managed } \\
\text { species-rich grasses, herbs and multiple cover } \\
\text { crops), providing food and habitats for spiders, } \\
\text { insects (e.g. bees, ground beetles, } \\
\text { Ichneumonidae, ladybirds that are important for } \\
\text { pollination and pest control), birds (such as } \\
\text { skylarks, partridges and birds of prey), } \\
\text { mammals as well as amphibians (in ecologically } \\
\text { designed flood retention pools) }\end{array}$ \\
\hline $\begin{array}{l}\text { Increase of ecological } \\
\text { connectivity }\end{array}$ & $\begin{array}{l}\text { Facilitating circulation of fauna in landscapes } \\
\text { dominated by crops. Creation of ecological } \\
\text { corridors for various kinds of animals, including } \\
\text { potentially slow moving earth or water-bound } \\
\text { species. Increase of genetic exchanges between } \\
\text { distant populations of the same species }\end{array}$ \\
\hline Adsorption of pollutants & $\begin{array}{l}\text { Transported by runoff and wind (dust), hence } \\
\text { cleaner surface water, groundwater and air }\end{array}$ \\
\hline $\begin{array}{l}\text { Reduction of negative off-Site } \\
\text { effects }\end{array}$ & $\begin{array}{l}\text { Such as sediment deposits on cropland, } \\
\text { infrastructure and private property, } \\
\text { psychological stress to inhabitants that were } \\
\text { frequently affected by muddy floods }\end{array}$ \\
\hline Enhanced quality of landscapes & $\begin{array}{l}\text { Predominantly consisting of cropland through } \\
\text { the installation of green corridors (grass buffer } \\
\text { strips, grassed waterways and cover crops) and } \\
\text { blue measures (such as flood retention ponds), } \\
\text { which lead to an improved recreational } \\
\text { attractiveness }\end{array}$ \\
\hline
\end{tabular}


For those working in the field of bioengineering, a specific framework is required at three levels:

(i). Questions: identification of the technical, socio-economic, and ecological problems, evaluated by the practitioners. Researchers and practitioners should then work together to solve specific objectives.

(ii). Applied research: translation of the technical, socioeconomic, and ecological concerns into scientific questions, and increase of knowledge by observations and experiments. Soil and water bioengineering can be implemented based on relevant knowledge from several scientific domains, especially geosciences (e.g., geomorphology and soil science), ecology (e.g., restoration ecology, landscape ecology, and plant sciences), engineering (e.g., fluvial hydraulics, civil and geotechnical engineering), sociology (e.g. community engagement and social acceptability of the methods and tools proposed; legitimate design approach), and economics (e.g. project financial management, carbon accounting) (Petrone and Preti, 2010; Stock and Burton, 2011).

(iii). Management in bioengineering: as soil and water bioengineering is consistent with policies aimed at encouraging "soft" solutions, in particular by including environmental concerns into standard technical practices such as civil engineering, it is essential that current and improved knowledge is included at the work design stage. For example, features such as natural wood deterioration rates (Barré et al., 2017; Tardio and Mickovski, 2016), plant development and successional trajectories (Walker et al., 2009; Gonzalez-Ollauri and Mickovski, 2017a), must be incorporated into the routines and protocols of bioengineering projects. Research results should then be used to develop methods and tools to assist management, conceptualization and action. Adaptation of these tools needs to be performed in collaboration with practitioners, while the knowledge transfer and learning should occur in training courses at every educational level (Mitsch, 2014; Mickovski et al., 2018). The application of knowledge to real cases using newly gained expertise should be verified. Long term monitoring programs, with accurate benchmark data, are also required to compare similar case studies and establish databases on the successes and failures of various techniques and plant material used (Tardío-Cerrillo and García-Rodriguez, 2016; Perez et al., 2017; Tardio et al., 2017). Such considerations should improve practitioners' understanding of recent knowledge in ecology and geosciences, as well as increasing scientists' understanding of practical needs in soil and water bioengineering.

For soil and water bioengineering, all the above features are essential and, for a project to be successful, close interactions between stakeholders and bioengineers are necessary. Improved communication and interaction between the stakeholders will allow bioengineering interventions to both become more effective over time and take advantage of the accumulated experience within the sector.

\section{Natural hazard control and/or ecological restoration?}

Depending on the precise objective of a project, the choice of the bioengineering intervention and the desired long-term strategy can vary considerably. For example, soil or streambed erosion can cause different types of damage: (i) loss of topsoil, organic matter and nutrients, which lowers soil quality and hence crop yields and, in turn, threatens agricultural activities (e.g., Jin et al., 2008); it can also cause imminent risk of structural failure of roads, bridges, and railway lines (e.g. Mickovski, 2014); (ii) topographic changes (terrain deformation) in the case of gully channel development, landslide triggering and suffusion risk phenomena (e.g. Poesen et al., 2003); (iii) biodiversity loss, which affects vegetation and animal habitats (Mkanda, 2002); (iv) silting of reservoirs, as a consequence of soil erosion and sediment transport, compromising the functioning of these structures (e.g. Schleiss et al., 2016) and (v) increased floods, caused by sediment deposition in river channels (e.g. Steiger et al., 2001). Strategies to control soil erosion rates will vary depending on the type of problem requiring action. For example, if reducing the sediment yield in rivers and reservoirs is the final objective, then the only intervention required is sediment control. Hence, it may be possible to allow hillslope erosion to take place, but to aim at trapping and retaining sediment before it reaches the river channel (Rey, 2009). If riverbed erosion causes lateral displacement and bank failures, and impacts nearby infrastructure, the main objective is to protect facilities with highly specialized and adapted bioengineering solutions, e.g. based on geotechnical preliminary investigations during design and monitoring stage (Peklo, 2015). However, if soil and biodiversity conservation are the final objectives, then both erosion control and ecological restoration are required to prevent soil particles from being detached and removed (Petrone and Preti, 2010).

The current challenge when using bioengineering techniques is to define rules that satisfy a set of diverse functions and benefits, particularly those that reconcile natural hazard control and ecological restoration (Fig. 2). This approach requires innovation from the practitioners, and also raises new questions for scientists, as part of an interactive process that necessitates the designing and testing of bioengineering actions that reconcile the competing demands of both natural hazard control and ecological restoration. As soil and fluvial bioengineering operates on complex systems (ecosystems) intrinsic adaptive management strategies and feedback loops are necessary to ensure that the project and the intervention is well informed.

\section{From practice to research needs}

One of the currently pressing challenges is to define bioengineering actions for a range of different situations. Although techniques are well described (e.g., Schiechtl and Stern, 1996, 1997; Gray and Sotir, 1996; Zeh, 2007; Florineth, 2007; Hacker and Johanssen, 2012; EFIB, 2015), quantitative recommendations on how and which materials to use in specific situations are lacking, especially when the objective is to reconcile natural hazard mitigation and ecological restoration. To overcome this knowledge gap, scientists should heed practitioners' needs through discussions during projects, conferences or training, and conduct research at different spatial scales, with specific objectives in mind (Fig. 3).

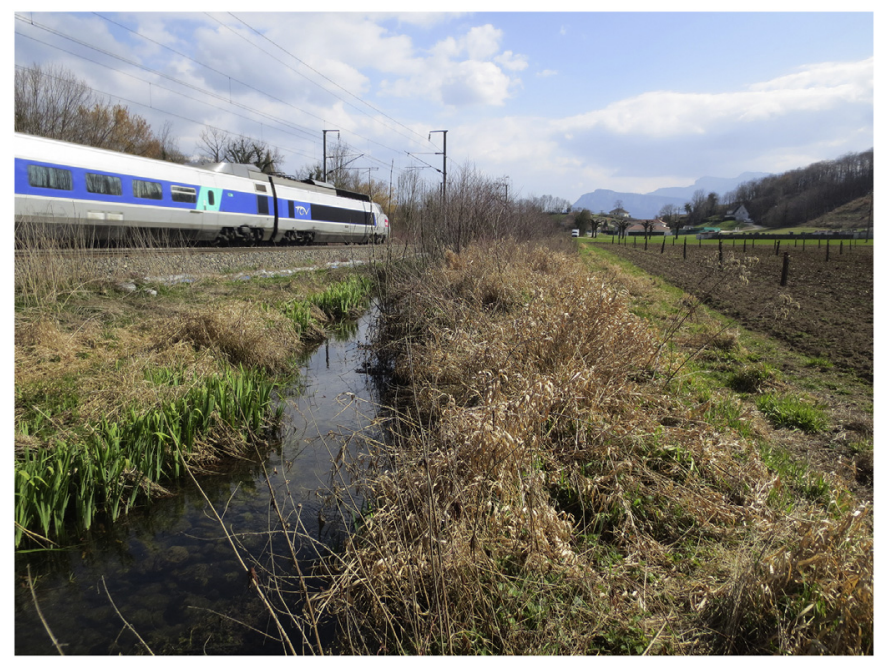

Fig. 2. Which bioengineering structures to use to restore this degraded stream while protecting the railway against floods? (photo: F. Rey). 


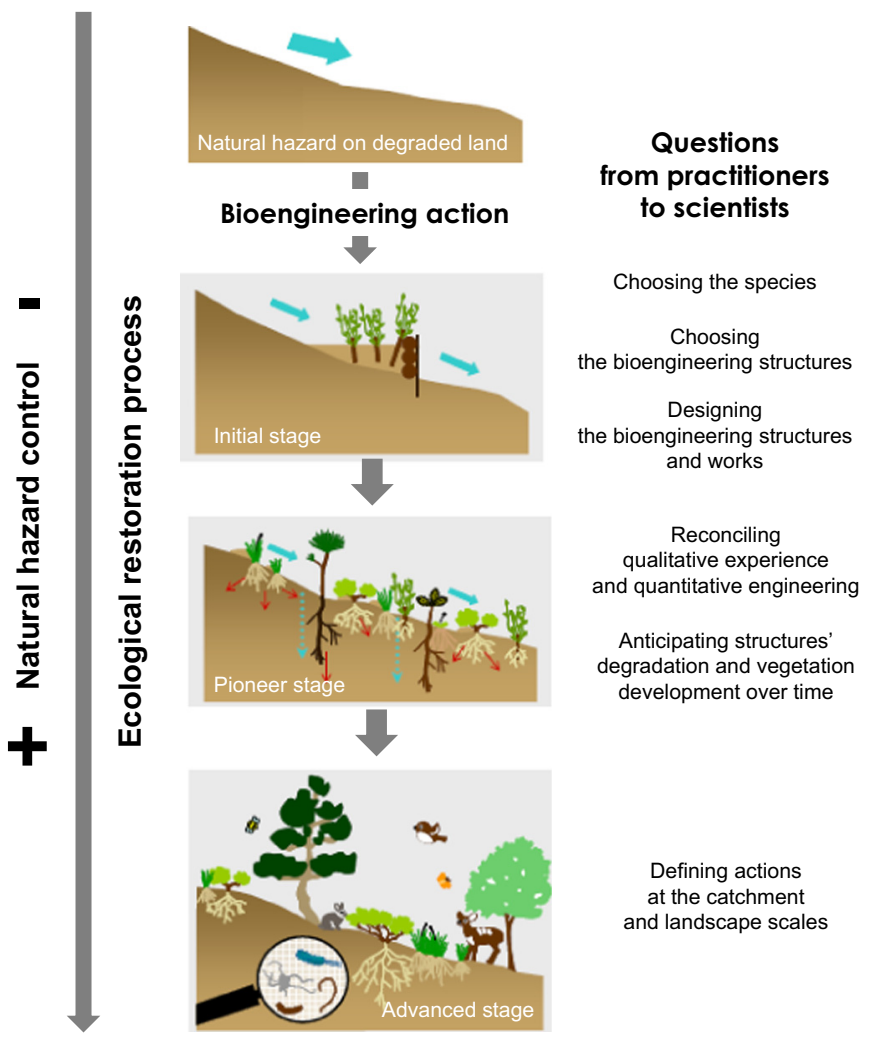

Fig. 3. Questions arising from practitioners showing how research objectives should be defined throughout the life of a bioengineering intervention, and the consequences for the ecological trajectory of a bioengineering structure. Such an approach would lead to improved natural hazard control and ecological restoration of a degraded site (Burylo and Rey, unpublished).

\subsection{Selection of plant species}

Numerous studies have already dealt with the performance of specific species in protecting against different hazards (e.g. plant species potential to control gully erosion rates in a Mediterranean ecosystem; De Baets et al., 2009), in a specific climate (Gonzalez-Ollauri and Mickovski, 2016), environment or topographic location (Bochet et al., 2009). Furthermore, an open access plant species database has recently been developed by Perez et al. (2017), allowing users to access the database or add information about species suitable for controlling erosion and shallow landslides in different climates. Traditionally, a limited number of plant species has been used for this purpose, although there are countless species available that could perform equally well, many of which have not yet been tested for suitability (Preti and Petrone, 2013; Perez et al., 2017). In general, although using pioneering species in soil bioengineering projects is sometimes necessary to initiate the successional processes that will maintain vegetation on the site, native species should be preferred over exotic species and ecological succession trajectories should be included in the bioengineering intervention design (Clemente et al., 2016; Xiao et al., 2017).

When choosing which species to use on a site, and considering ecological restoration principles, the local and regional environmental conditions need to be considered carefully, so that an optimal and sustainable system is created (Mickovski and Van Beek, 2006). For the successful creation of a bioengineering system, the initial phase is of major importance. For the last 30 years, practitioners and scientists have been studying the installation phase, by e.g. examining the relationship between the richness of pioneer species and soil aggregate stability (Pohl et al., 2012), or the efficacy of using mycorrhizal inoculations to improve plant growth and soil structure on eroded soil (Powell,
1980; Yildiz et al., 2015; Bast et al., 2016; Demenois et al., 2017). These studies concluded that the key to fully understanding ecological processes at eroded sites requires similar long-term experiments in the field.

Species adapted for hazard protection are not necessarily those used for ecological restoration. One of the most difficult questions a manager can ask is: is it better to use only one or a few species that can efficiently mitigate a specific hazard, or should a diverse range of species, sometimes less efficient, be used? Promoting species diversity is generally recommended in ecological restoration projects, but could an increased diversity result in less effective hazard control? Investigating this problem, Erktan et al. (2013) showed that a morphological diversity of plant species used in vegetation barriers did not increase sediment retention in eroded marly gully floors in the French Southern Alps, compared to monospecific barriers (Fig. 4). Such a consideration of plant biodiversity is a critical issue, as it generally corresponds to a more ecologically stable system (Preti and Petrone, 2013). A stable and healthy planting system would be less vulnerable to abiotic (e.g., flooding, storms, snow loading and landslides) and biotic stress (e.g., pathogens and grazing). A diversity of plant species would also enable a manager to "cover all options"; for example in the case of a particular species becoming susceptible to abiotic/biotic factors, the loss of one species would be less likely to compromise the aims of the project. Referring to the study of Erktan et al. (2013), Rey and Labonne (2015) suggested using only one species to build brush layers and mats in eroded gully floors, but to use different species between structures along the gully floor, thus reconciling natural hazard mitigation with improved biodiversity.

\subsection{Selection of bioengineering structures}

The choice of the appropriate structure to use in a bioengineering project largely depends on the objective. When considering natural hazard control, the first principle to follow is to use structures and plants that have sufficient mechanical resistance to withstand gravitational or hydrological forces linked to the hazard process. Firstly, although technical drawings describing structures and their mechanical resistance exist in guidelines, we do not necessarily know their origins and performance or reliability for the myriad of field situations likely to be encountered (Schaff et al., 2013). With the exception of gravitational structures (e.g. crib walls and fascines), whose design procedures are well established, and apart from a few cases (e.g. brushlayers and riverbank protection, Bischetti et al., 2010), most bioengineering techniques have not yet been sufficiently studied. At the individual plant scale, it is not well known to which topographic (e.g. Bochet et al., 2009; NadalRomero et al., 2014) and hydrological forces plants resist before failing,

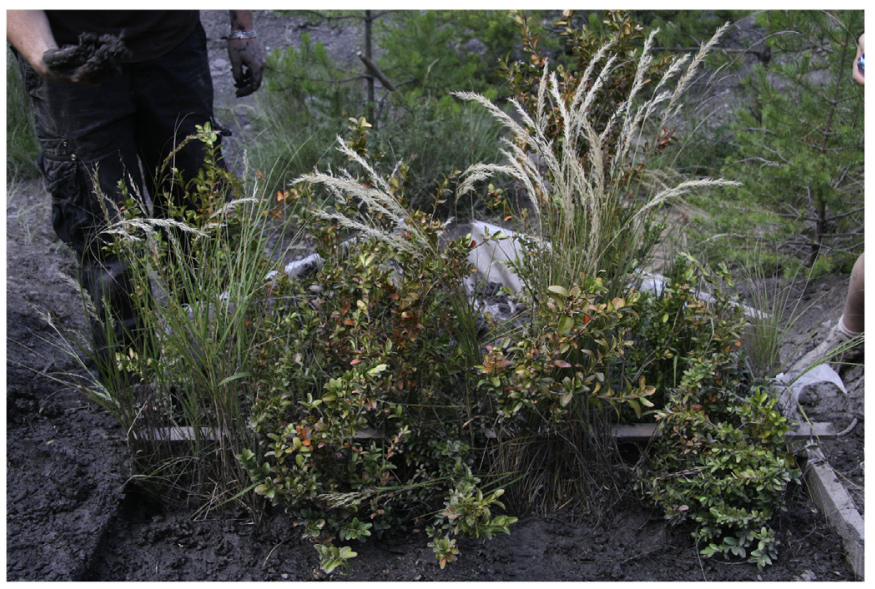

Fig. 4. Biodiversity can have a negative effect on sediment trapping performance of vegetation barriers, as monospecific barriers involving one very performant species are more efficient than plurispecific ones including more or less efficient species (photo: $F$. Rey). 
and which plant traits are important for mechanical resistance (Burylo et al., 2014), therefore this topic needs significantly more attention from the scientific community. Questions also remain concerning the types of hazard and their different return periods depending on geographic situation and climate, especially under extreme climates such as in tropical countries. This knowledge gap calls for large-scale experiments taking into consideration all the variables and elements to which the structures are subjected (Schwarz et al., 2012). Secondly, it should be kept in mind that certain plant species or conditions may destabilize a structure. For example, along river embankments, vegetated crib walls (Fig. 1D) can act as a slope buttress or slope break when placed on an eroding embankment to mitigate gully erosion processes (Florineth, 2007). Vegetated crib walls help protect the shoreline and promote revegetation because plants are incorporated within the structure and root growth stabilizes soil. Although some long-term observations have demonstrated that root development and tree stem growth did not adversely affect the structure of vegetated crib walls (K. Peklo, unpublished data), practitioners may hesitate to choose this type of structure because of the way that vegetation interacts with the structure over time.

There is a need to assess more precisely the interrelationships between inert and living materials in bioengineering structures. Questions remain, in particular with regard to wooden structures, where wood decay has to be assessed over time, as vegetation grows and develops around the structure (Barré et al., 2017). Although the role of plants in stabilizing slopes over the long-term is crucial, the growth dynamics of plants used in bioengineering structures are basically unknown and more research is needed to address this gap. Questions particularly arise with regard to the desirable biodegradation of wooden structures. When inert structures are used to enhance vegetation development, for example certain small-scale wooden structures, their initial rigidity has to allow the triggering of new natural processes such as an improved resilience, an improved ecological functioning, and vegetation succession processes, before these inert structures disappear (Stokes et al., 2014). The initial rigidity achieved by means of the inert elements used in the bioengineering intervention must exist long enough so that plants are capable of developing their reinforcing effect. This evolution must be reflected well at the design stage related to a predefined construction aim. Deterioration models of the material used in the work (such as wood) must also be included in the design (Tardio and Mickovski, 2016). All these considerations call for research to evaluate the level and speed of decay of wooden structures, as well as the dynamics of vegetation within bioengineering structures, in relation to the development and diversification of vegetation and to the desired stage of natural hazard mitigation (Barré et al., 2017).

Finally, a maintenance schedule of the living material used in bioengineering structures may be required. These maintenance tasks are usually needed to avoid vegetation becoming too heavy, resulting in the overturning of the bioengineering structure. On riverbanks, this maintenance should also aim at keeping vegetation flexible enough to avoid excessive hydraulic resistance, which can cause an increase of water levels, and to reduce stem and branch breakage, which produce debris obstructing bridges and narrow sections of the river (EFIB, 2015).

\subsection{Design of bioengineering structures}

To improve the adoption of bioengineering methods by a wider community, new tools (e.g. soil-vegetation interaction models, technological frameworks, enhanced methodological approaches and guidelines) must be developed for use in the design of bioengineering structures. In particular, it is necessary to know how to use living plants to attain the expected objectives, and to predict the spatial-temporal development of the installed bioengineering structure, while considering the climate and ecological conditions of the site. During the pre-design phase, the designer must be able to decide if the bioengineering techniques are feasible or must be used in combination with other conventional techniques (so called 'mixed' techniques), in order to improve the resistance of the structure and resilience of the system. Finally, a global, long-term vision of the project at all spatial scales, from local to catchment, is needed.

Improved knowledge is required to design bioengineering structures and optimize their performance in terms of hazard mitigation while enhancing plant diversity. For example, where is it most effective to install a structure at a site? How many plants or cuttings should be used within a structure? Particular attention should be paid to improving our understanding of the efficiency of different plant species and their traits, depending on the final goal of the intervention (Burylo et al., 2014). To design technical solutions, the bioengineer can sometimes use physical scale models. This approach is often not feasible, as plant effects on e.g. slope stability or erosion control and the impact of vegetation on discharge capacity cannot be downscaled appropriately at reasonable laboratory scales such as 1:30 to 1:40 (Wilson et al., 2006). Prototype scale (1:1) tests remain a viable solution for scientists and practitioners, but are often not feasible because of time, space, and cost (Schwarz et al., 2012). Therefore, most engineers use readily available numerical geotechnical models that include the effects of vegetation. Different types of models have been implemented over the years to predict landslide risk (see Stokes et al., 2014; Gonzalez-Ollauri and Mickovski, 2017b), many of which calculate a global Factor of Safety (FoS) at the slope level, but are not suitable for calculating the efficacy of individual bioengineering structures. Several uncertainties exist in model parameters, which can be overcome by using a probabilistic approach to e.g. synchronize the mechanical behavior of roots and soil throughout the development of the shear surface (Tardio and Mickovski, 2015). Further information on the hydrological effects of root water uptake is also required, particularly for herbs, shrubs and trees (Chirico et al., 2013; Tron et al., 2014; Arnone et al., 2016; Kim et al., 2017). Upscaling to the catchment level is still a significant challenge, partially because of a lack of suitable data to either parameterize or validate models, but also because of a lack of understanding of biophysical processes at different scales. However, Rossi et al. (2017) demonstrate that the physical landslide model LAPSUS_LS is suitable for calculating the effects of vegetation on slope stability at the catchment level. Nevertheless, parallel studies should investigate how soil hydrological and physical processes at the slope level are altered over a larger scale and vice versa (Bogaard and Greco, 2015).

\subsection{Reconciling qualitative experience and quantitative engineering}

Statutory constraints related to building structures used for natural hazard control require quantitative engineering methodology, whereas bioengineering often, but not always, comprises more qualitative experience. Thus there is a need to develop research that will reconcile these qualitative and quantitative issues for natural hazard control, but also for ecosystem restoration. Methods for identifying precise performance thresholds for bioengineering installations at local scales could be very helpful. Questions to ask include: (i) is a stepwise strategy necessary and therefore an initial plant protection plan needed? (ii) what is the most efficient spatial distribution of bioengineering structures and plants for hazard control with regard to the physical forces to which they are subjected? (iii) what is the necessary, but adequate, rate of vegetation cover to control a given natural hazard, while considering also ecological processes at this spatial level? Answers to these questions are strongly related to the objectives, which will be different in the case of natural hazard mitigation or ecological restoration. A need also expressed by practitioners is to define appropriate indicators that allow managers to determine the thresholds of efficiency when reconciling natural hazard control and ecological restoration. Finally, the need for case study analysis in terms of bioengineering work performance has been suggested as a useful tool for proposing improvements at the design, construction, and monitoring stages. 
One further crucial issue determining the success of a bioengineering project is to know if bioengineers can have the financial freedom to create the "best" solution to each problem (EFIB, 2014). For example, for a project in which ecological restoration is required and when significant financial means can be used to implement optimal actions, such actions are able to achieve effective restoration, and enable the damaged ecosystem to recover its original condition. But when constraints are imposed in budgeting and financing bioengineering projects, such as in underdeveloped countries, it is necessary to minimize interventions. In this later case, complete 'restoration' is not economically possible. Therefore, recovering the ecosystem to a state before degradation is not the final objective, but reaching a specific ecosystem objective in line with the current technical, socio-economic and ecological problems, such as controlling a specific natural hazard, becomes the main aim (Rey, 2009). This situation also calls for reconciling possible qualitative issues linked to the definition of precise objectives of a bioengineering project, and quantitative engineering, corresponding to the design of the bioengineering structures and the related financial means.

\subsection{Defining actions at the catchment and landscape scales}

Soil and water bioengineering techniques are usually targeted to discrete locations, whereas their design often needs to be considered at the catchment and landscape scales (Bifulco et al., 2015). The variables with the greatest influence on a bioengineering structure's final design are usually structural, hydraulic or related to plant characteristics, especially when natural hazard mitigation is the main objective. Using bioengineering for natural hazard mitigation at the catchment scale, especially with regard to water and sediment transport, implies taking into account the connectivity between slopes and the river or gully channel, and between upstream and downstream parts of the catchment. For example with respect to flood reduction, a key objective can be to reduce runoff and particularly to interrupt the fine sediment connectivity between various parts of the catchment (e.g. Verstraeten et al., 2006; Borselli et al., 2008; Rey and Burylo, 2014; Mekonnen et al., 2015). The spatial distribution of control measures such as planted areas also needs to be considered at the wider catchment scale, as does the climatic regime. In some cases it will be possible to provide a level of control for more frequent climatic events that generate sediment. Nevertheless, designing structures or bioengineering solutions to deal with extreme, infrequent or high magnitude events remains problematic.

The need to define strategies for bioengineering at the catchment and landscape scales is well illustrated in the framework of Green infrastructure (GI), interconnected networks of natural or semi-natural sites able to provide environmental, social, and economic benefits to human populations (known as ecosystem services). Soil bioengineering can play a fundamental role in creating networks because their capability is to bridge natural and man-made environments. It allows the restoration of ecosystems and is an effective tool in the implementation of GI (EFIB, 2014). Although GI is included in several EU and International Agencies programs and policies (e.g. EU 2020 Biodiversity Strategy, Natura 2000, UNEP-DHI 2014 Green Infrastructure Guide for Water Management), the use of soil bioengineering techniques is generally implicit. The success in implementing a GI strategy strongly depends on the achievements of bioengineers. Soil bioengineering techniques, by including vegetation as an intrinsic component of installations, are able to provide several functions, such as slope and riverbank stabilization and protection from soil erosion, as well as habitat for animals, microclimate regulation and recreational use (Table 1, Stokes et al., 2014). Therefore, design of bioengineering structures can be thought for allowing them to provide both slope stabilization and ecological restoration (Fig. 5).

The Blue infrastructures (BI) framework is also a good illustration of the complex questions facing bioengineers. Worldwide, two contrary eco-geomorphological management practices co-exist for rivers. In

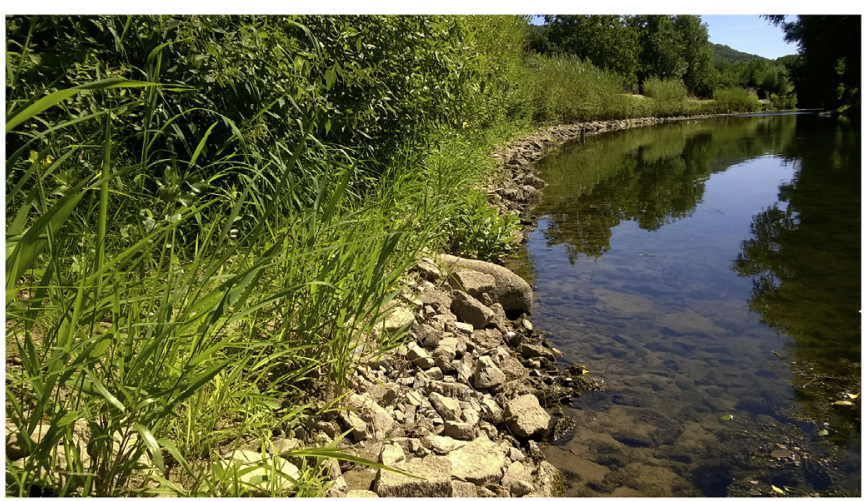

Fig. 5. Design of bioengineering structures along riverbanks can be thought for allowing them to provide both slope stabilization and ecological restoration (photo: K. Peklo).

some catchments, aggradation of the river channel occurs, a phenomenon caused by excessive fine sediment in the river. Habitats for fish reproduction may be damaged, flood risks increase, and hydroelectric reservoirs can fill with sediment (Rey, 2009). In contrast, other catchments suffer from a lack of bed load in the river. As a consequence, groundwater levels can decrease and river beds incise, causing damage such as bridge destabilization (Liébault et al., 2005). Vegetation cover in the surrounding landscape is an important factor controlling the erosion responsible for sediment yield in rivers. In case of bedload excess, eroding slopes and riverbanks are controlled through bioengineering measures and revegetation efforts, considered as restoration actions on degraded land (e.g., Vallauri et al., 2002). Conversely, where a deficit of bedload exists, slope erosion can be reactivated by destroying the vegetation on highly erodible soils. Sometimes, both situations coexist within the river's catchment, but generally in different parts and at different times, as stated by Liébault et al. (2005) who recorded both aggradation followed by degradation in the same catchment prereforestation and post-reforestation. Thus the influence of vegetation on a river's sediment production, especially in mountainous areas, is often difficult to understand.

Another situation showing the difficulty in reconciling natural hazard mitigation and ecological restoration is the management of dams on rivers. These structures often have a role in managing floods and many have been constructed over a century ago in different countries (e.g., Vallauri et al., 2002 on French experience). However, today these structures are blamed for representing obstacles to aquatic fauna, and programs for removing them are developed, calling into question the impact of this kind of action on the river's stability. One solution consists in replacing dams with rough rock ramps with integrated fishway (Fig. 6). All these examples call for more discussion between scientists and practitioners, as well as a better assessment of current knowledge. There is an urgent need to consider new research strategies and to determine whether ecological restoration actions should be carried out on areas where natural hazards occur, with different ecological and socio-economic issues calling for different solutions in the management of these hazards.

\section{Conclusion}

In the sections above, we highlighted the practice and research needs in soil and water bioengineering through a critical review of the definition and development of bioengineering technology, while stressing the issues about the design, implementation, and monitoring of bioengineering actions. Based on the critical analysis presented above, we conclude that there is a need to reconcile natural hazard control and ecological restoration by posing new applied research questions aimed at meeting this purpose. More importantly, there is a need to define sound techniques that reconcile natural hazard control and ecological restoration. The key considerations helping succeeding 


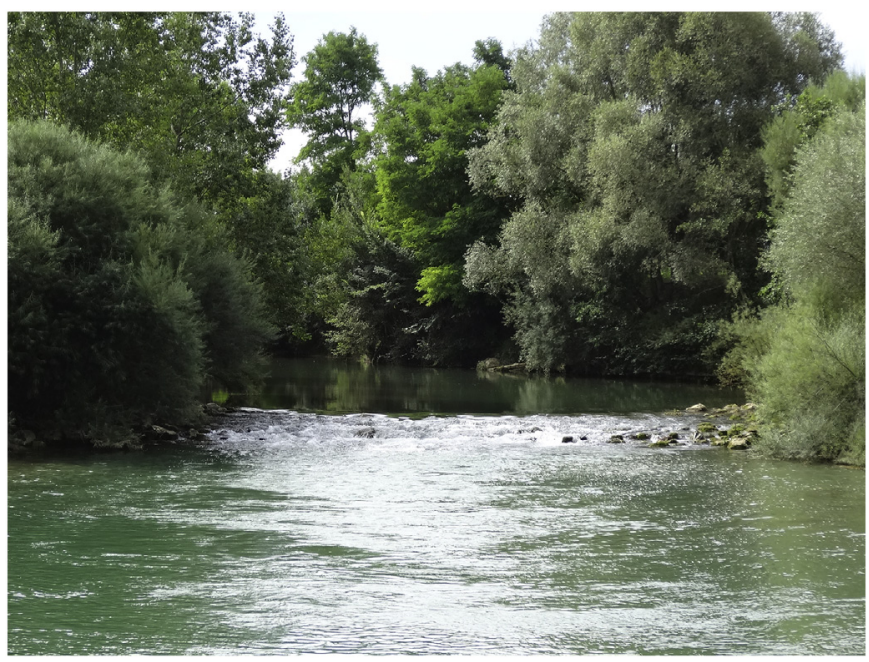

Fig. 6. Rough rock ramp with integrated fishway, providing positive action for both riverbed stabilization and fish movement (photo: K. Peklo).

bioengineering actions in the future can be summarized as: (i) considering a multidisciplinary approach for soil and water bioengineering projects, (ii) establishing practical guidelines and tools for designing bioengineering structures, (iii) implementing monitoring stages in bioengineering projects, (iv) transmitting knowledge and know-how on soil and water bioengineering, (v) analyzing existing bioengineering works in terms of their performance, successes and failures, and (vi) continuing to identify the needs of the bioengineering professional sector.

\section{Acknowledgements}

We thank the French "Ministère de la transition écologique et solidaire" and the H2020 Erasmus project ECOMED (575976-EPP-12016-1-ES-EPPKA2-K1) for financial support. We also thank Mélanie Burylo for ideas and graphical assistance in Fig. 2. This paper has been initiated from a discussion at the 4th International Conference "Soil bio- and eco-engineering: the use of vegetation to improve slope stability" which was held from 11 to 14 July 2016 at the University of Sydney, Australia. We are grateful to members of the European Federation for Soil Bioengineering (EFIB) for useful discussion. Funding was provided (A.S.) by theTALVEG2 project (funded by Région LanguedocRoussillon-Midi-Pyrénées and Projet Collaboratif Régional fond FEDER) and the BMU (Germany) International Climate Initiative funded project "Ecosystems Protecting Infrastructure and Communities" (EPIC). Finally the authors greatly thank the four anonymous reviewers for their helpful comments.

\section{References}

Arnone, E., Caracciolo, D., Noto, L.V., Preti, F., Bras, R.L., 2016. Modeling the hydrological and mechanical effect of roots on shallow landslides. Water Resour. Res. 52, $8590-8612$

Aronson, J., Floret, C., Le Floc'h, E., Ovalle, C., Pontanier, R., 1993. Restoration and rehabilitation of degraded ecosystems in arid and semi-arid lands. I. A view from the south. Restor. Ecol. 1, 8-17.

Barker, D.H., Watson, A.J., Sombatpanit, S., Northcutt, B., Magliano, A.R. (Eds.), 2004 Ground and Water Bioengineering for Erosion Control and Slope Stabilization. Science Publishers Inc., Enfield, NH.

Barré, J.B.B., Bourrier, F., Bertrand, D., Thévenon, M.F., Rey, F., 2017. Assessment of the level of decay of small-diameter silver fir logs degraded in natural conditions in the French Northern Alps using two different methods. Ecol. Eng. 109, 240-248.

Bast, A., Wilcke, W., Graf, F., Lüscher, P., Gärtner, H., 2016. Does mycorrhizal inoculation improve plant survival, aggregate stability, and fine root development on a coarsegrained soil in an alpine eco-engineering field experiment? J. Geophys. Res. Biogeosci. $121,2158-2171$

Bifulco, C., Pereira, A., Ferreira, V., Mota, A., Martins, L., Rego, F., 2015. Renewing dangerous highway slopes in Portugal. Ingenieurbiologie 3, 43-50.
Bischetti, G.B., Chiaradia, E.A., D'Agostino, V., Simonato, T., 2010. Quantifying the effect of brush layering on slope stability. Ecol. Eng. 36, 258-264.

Bischetti, G.B., Di Fi Dio, M., Florineth, F., 2014. On the origin of soil bioengineering. Landsc. Res. 1-13.

Bochet, E., Garcia-Fayos, P., Poesen, J., 2009. Topographic thresholds for plant colonization on semi-arid eroded slopes. Earth Surf. Process. Landf. 34, 1758-1771.

Bogaard, T.A., Greco, R., 2015. Landslide hydrology: from hydrology to pore pressure. Wiley Interdiscip. Rev. Water 3, 439-459.

Borselli, L., Cassi, P., Torri, D., 2008. Prolegomena to sediment and flow connectivity in the landscape: a GIS and field numerical assessment. Catena 75, 268-277.

Bresci, F., Preti, F., 2010. A historical survey on the evolution of some forest watershed management techniques (part II: stream channel works). J. Agric. Eng. Res. 13-22.

Burylo, M., Dutoit, T., Rey, F., 2014. Species traits as practical tools for ecological restoration of marly eroded lands. Restor. Ecol. 22, 633-640.

Chirico, G.B., Borga, M., Tarolli, P., Rigon, R., Preti, F., 2013. Role of vegetation on slope stability under transient unsaturated conditions. Procedia Environ Sci 19, 932-941.

Clemente, A.S., Moedas, A.R., Oliveira, G., Martins-Loução, M.A., Correia, O., 2016. Effect of hydroseeding components on the germination of Mediterranean native plant species. J. Arid Environ. 125, 68-72.

Clewell, A.F., Aronson, J., 2013. Ecological restoration: principles, values, and structure of an emerging profession. Society for Ecological Restoration 336.

De Baets, S., Poesen, J., Reubens, B., Muys, B., De Baerdemaeker, J., Meersmans, J., 2009. Methodological framework to select plant species for controlling rill and gully erosion: application to a Mediterranean ecosystem. Earth Surf. Process. Landf. 34, 1374-1392.

Demenois, J., Rey, F., Stokes, A., Carriconde, F., 2017. Does arbuscular and ectomycorrhizal fungal inoculation improve soil aggregate stability? A case study on three tropical species growing in ultramafic Ferralsols. Pedobiologia 64, 8-14.

Dhital, Y.P., Kayastha, R.B., Shi, J., 2013. Soil bioengineering application and practices in Nepal. Environ. Manag. 51, 354-364.

Dhital, Y.P., Tang, Q., 2015. Soil bioengineering application for flood hazard minimization in the foothills of Siwaliks, Nepal. Ecol. Eng. 74, 458-462.

EFIB, 2014. Soil and Water Bioengineering and Green Infrastructure. VIIle Congress EFIBAEIP-APENA Vitoria Gasteiz, Spain.

EFIB, 2015. European Guidelines for Soil and Water Bioengineering. European Federation of Soil Bioengineering.

Erktan, A., Cécillon, L., Roose, E., Frascaria-Lacoste, N., Rey, F., 2013. Morphological diversity of plant barriers does not increase sediment retention in eroded marly gullies under ecological rehabilitation (Southern Alps, France). Plant Soil 370, 653-669.

European Commission, 2013. Communication From the Commission to the European Parliament, the Council, the European Economic and Social Committee and the Committee of the Regions 'Green Infrastructure (GI) - Enhancing Europe's Natural Capital' (COM/2013/0249 final).

Florineth, F., 2007. Bioengineering methods of strengthening slopes in the Alps: protection of deep soil and subsoil horizons. J. Environ. Plan. Manag. 2, 35-45.

Furuta, N., Monty, F., Murti, R., 2016. Helping Nature Help Us: Transforming Disaster Risk Reduction through Ecosystem Management. IUCN Publication, Switzerland.

Gonzalez-Ollauri, A., Mickovski, S.B., 2016. Using the root spread information of pioneer plants to quantify their mitigation potential against shallow landslides and erosion intemperate humid climates. Ecol. Eng. 95, 302-315.

Gonzalez-Ollauri, A., Mickovski, S.B., 2017a. Plant-soil reinforcement response under different soil hydrological regimes. Geoderma 285, 141-150.

Gonzalez-Ollauri, A., Mickovski, S.B., 2017b. Shallow landslides as drivers for slope ecosystems evolution and biophysical diversity. Landslides 14, 1699-1714.

Graf, F., Frei, M., 2013. Soil aggregate stability related to soil density, root length, and mycorrhiza using site-specific Alnus incana and Melanogaster variegatus s.l. Ecol. Eng. 57, 314-323.

Gray, D.H., Sotir, R.B., 1996. Biotechnical and Soil Bioengineering Slope Stabilization: A Practical Guide for Erosion Control. John Wiley \& Sons, New York, NY.

Hacker, E., Johanssen, R., 2012. Ingenieurbiologie. Eugen Ulmer KG, Stuttgart.

Jin, K., Cornelis, W.M., Gabriels, D., Schiettecatte, W., De Neve, S., Lu, J., Buysse, T., Harmann, R., 2008. Soil management effects on runoff and soil loss from field rainfall simulation. Catena 75, 191-199.

Kim, J.H., Fourcaud, T., Jourdan, C., Maeght, J.L., Mao, Z., Metayer, J., Meylan, L., Pierret, A., Rapidel, B., Roupsard, O., de Rouw, A., Villatoro Sanchez, M., Wang, Y., Stokes, A., 2017. Vegetation as a driver of temporal variations in slope stability: the impact of hydrological processes. Geophys. Res. Lett. 44, 4897-4907.

Li, X., Zhang, L., Zhang, Z., 2006. Soil bioengineering and the ecological restoration of riverbanks at the Airport Town, Shanghai, China. Ecol. Eng. 26, 304-314.

Liébault, F., Gomez, B., Page, M., Marden, M., Peacock, D., Richard, D., Trotter, C.M., 2005. Land-use change, sediment production and channel response in upland regions. River Res. Appl. 21, 739-756.

Lin, W.T., Lin, C.Y., Chou, W.C., 2006. Assessment of vegetation recovery and soil erosion at landslides caused by a catastrophic earthquake: a case study in Central Taiwan. Ecol. Eng. 28, 79-89.

Mekonnen, M., Keesstra, S., Stroosnijder, L., Baartman, J., Maroulis, J., 2015. Soil conservation through sediment trapping: a review. Land Degrad. Dev. 26, 544-556.

Mickovski, S.B., 2014. Resilient design of landslip prevention measures: a case study. Proceedings of the ICE - forensic. Engineering 168, 96-106.

Mickovski, S.B., Tardio Cerrillo, G., Sangalli, P., Perez, J., Thomson, C.S., Gallagher, C., 2018. Development of eco-engineering sector specific routines and curricula for the Mediterranean region. In: Kallel, A., Ksibi, M., Ben Dhia, H., Khélifi, N. (Eds.), Recent Advances in Environmental Science from the Euro-Mediterranean and Surrounding Regions. EMCEI 2017. Advances in Science, Technology \& Innovation (IEREK Interdisciplinary Series for Sustainable Development). Springer, Cham, pp. 937-939.

Mickovski, S.B., Van Beek, L.P.H., 2006. A decision support system for the evaluation of eco-engineering strategies for slope protection. Geotech. Geol. Eng. 24, 483-498. 
Mitsch, W.J., 2012. What is ecological engineering? Ecol. Eng. 45, 5-12.

Mitsch, W.J., 2014. When will ecologists learn engineering and engineers learn ecology? Ecol. Eng. 65, 9-14.

Mitsch, W.J., Jørgensen, S.E., 2003. Ecological engineering: a field whose time has come. Ecol. Eng. 20, 363-377.

Mitsch, W.J., Jørgensen, S.E., 2004. Ecological Engineering and Ecosystem Restoration. John Wiley \& Sons.

Mkanda, F.X., 2002. Contribution by farmers' survival strategies to soil erosion in the Linthipe River Catchment: implications for biodiversity conservation in Lake Malawi/Nyasa. Biodivers. Conserv. 11, 1327-1359.

Nadal-Romero, E., Petrlic, K., Verachtert, E., Bochet, E., Poesen, J., 2014. Effects of slope angle and aspect on plant cover and species richness in a humid Mediterranean badland. Earth Surf. Process. Landf. 39, 1705-1716.

Norris, J.E., Stokes, A., Mickovski, S.B., Cammeraat, E., van Beek, R., Nicoll, B.C., Aachim, A. (Eds.), 2008. Slope Stability and Erosion Control: Ecotechnological Solutions. Springer, Dordrecht, The Netherlands.

Peklo, K., 2015. L'apport d'un programme de modélisation hydrodynamique bidimensionnel au travail de l'ingénieur. Ingenieurbiologie 3, 13-17.

Perez, J., Condes Salazaar, R., Stokes, A., 2017. An open access database of plant species useful for controlling soil erosion and substrate mass movement. Ecol. Eng. 99, 530-534.

Petrone, A., Preti, F., 2010. Soil bioengineering for risk mitigation and environmental restoration in a humid tropical area. Hydrol. Earth Syst. Sci. 14, 239-250.

Phillips, C.J., Rey, F., Marden, M., Liébault, F., 2013. Revegetation of degraded steeplands in France and New Zealand: a comparison of geomorphic and policy responses. N. Z. J. For. Sci. 43, 14

Poesen, J., 2017. Soil erosion in the Anthropocene: research needs. Earth Surf. Process. Landf. 43, 64-84.

Poesen, J., Nachtergaele, J., Verstraeten, G., Valentin, C., 2003. Gully erosion and environmental change: importance and research needs. Catena 50, 91-133.

Pohl, M., Graf, F., Buttler, A., Rixen, C., 2012. The relationship between plant species richness and soil aggregate stability can depend on disturbance. Plant Soil 355, 87-102.

Powell, C.L.L., 1980. Mycorrhizal infectivity of eroded soils. Soil Biol. Biochem. 12, 247-250.

Preti, F., Giadrossich, F., 2009. Root reinforcement and slope bioengineering stabilization by Spanish Broom (Spartium junceum L.). Hydrol. Earth Syst. Sci. 13, 1713-1726.

Preti, F., Petrone, A., 2013. Soil bioengineering for watershed management and disaster mitigation in Ecuador: a short-term species suitability test. iForest 6, 95-99.

Pretty, J.L., Harrison, S.S.C., Shepherd, D.J., Smith, C., Hildrew, A.G., Hey, R.D., 2003. River rehabilitation and fish populations: assessing the benefit of instream structures. J. Appl. Ecol. 40, 251-265.

Rauch, H.P., Sutili, F.J., Hörbinger, S., 2014. Installation of a riparian forest by means of soil bio engineering techniques-monitoring results from a river restoration work in Southern Brazil. Open J. For. 4, 161-169.

Renaud, F.G., Sudmeier-Rieux, K., Estrella, M., Nehren, U. (Eds.), 2016. Ecosystem-Based Disaster Risk Reduction and Adaptation in Practice. Advances in Natural and Technological Hazards Research. Springer.

Rey, F., 2009. A strategy for fine sediment retention with bioengineering works in eroded marly catchments in a mountainous Mediterranean climate (Southern Alps, France). Land Degrad. Dev. 20, 210-216.

Rey, F., Burylo, M., 2014. Can bioengineering structures made of willow cuttings trap sediment in eroded marly gullies in a mountainous and Mediterranean climate (Southern Alps, France)? Geomorphology 204, 564-572.

Rey, F., Labonne, S., 2015. Resprout and survival of willow (Salix) cuttings in marly gullies in a mountainous Mediterranean climate: a real size experiment in the Francon catchment (Southern Alps, France). Environ. Manag. 56, 971-983.

Rossi, L.M.W., Rapidel, B., Roupsard, O., Villatoro, M., Mao, Z., Nespoulous, J., Perez, J., Metselaar, K., Schoorl, J.M., Claessens, L., Stokes, A., 2017. Sensitivity of the landslide model LAPSUS_LS to vegetation and soil parameters. Ecol. Eng. 109, 249-255.

Schaff, S.D., Pezeshki, S.R., Shields, F.D., 2013. Effects of soil conditions on survival and growth of black willow cuttings. Environ. Manag. 31, 748-763.

Schiechtl, H.M., Stern, R., 1996. Ground Bioengineering Techniques for Slope Protection and Erosion Control. Blackwell Science, Oxford, UK, p. 146.

Schiechtl, H.M., Stern, R., 1997. Water Bioengineering Techniques for Watercourse Bank and Shoreline Protection. Blackwell Science, Oxford, UK, p. 186.
Schleiss, A.J., Franca, M.J., Juez, C., De Cesare, G., 2016. Reservoir sedimentation, vision paper. J. Hydraul. Res. 54, 595-614.

Schwarz, M., Cohen, D., Or, D., 2012. Spatial characterization of root reinforcement at stand scale: theory and case study. Geomorphology 171-172, 190-200.

Smith, A.B., Katz, R.W., 2013. US billion-dollar weather and climate disasters: data sources, trends, accuracy and biases. Nat. Hazards 67, 387-410.

Steiger, J., Gurnell, A.M., Petts, G.E., 2001. Sediment deposition along the channel margins of a reach of the middle river Severn, UK. River Res. Appl. 17, 443-460.

Stock, P., Burton, R.J.F., 2011. Defining terms for integrated (multi-inter-trans-disciplinary) sustainability research. Sustain. For. 3, 1090-1113.

Stokes, A., Douglas, G., Fourcaud, T., Giadrossich, F., Gillies, C., Hubble, T., Kim, J.H., Loades, K., Mao, Z., Mclvor, I., Mickovski, S.B., Mitchell, S., Osman, N., Phillips, C., Poesen, J., Polster, D., Preti, F., Raymond, P., Rey, F., Schwarz, M., Walker, L.R., 2014. Ecological mitigation of hillslope instability: ten key issues facing practitioners and researchers. Plant Soil 377, 1-23.

Stokes, A., Raymond, P., Polster, D., Mitchell, S.J., 2013. Engineering the ecological mitigation of hillslope stability research into the scientific literature. Ecol. Eng. 61, 615-620.

Stokes, A., Spanos, I., Norris, J.E., Cammeraat, E., 2004. Eco- and Ground Bioengineering The Use of Vegetation to Improve Slope Stability. Developments in Plant and Soil Sciences. p. 103 (CD-ROM).

Tardio, G., Mickovski, S.B., 2015. Method for synchronisation of soil and root behaviour for assessment of stability of vegetated slopes. Journal of Ecological Engineering 82, 222-230.

Tardio, G., Mickovski, S.B., 2016. Implementation of eco-engineering design into existing slope stability design practices. Ecol. Eng. 92, 138-147.

Tardio, G., Mickovski, S.B., Stokes, A., Devkota, S., 2017. Bamboo structures as a resilient erosion control measure. Proc. Inst. Civ. Eng. 170, 72-83.

Tardío-Cerrillo, G., García-Rodriguez, J.L., 2016. Monitoring of erosion preventive structures based on eco-engineering approaches: the case of the mixed check dams of masonry and forest residues. Journal of Engineering Science and Technology Review 9, 103-107.

Tron, S., Dani, A., Laio, F., Preti, F., Ridolfi, L., 2014. Mean root depth estimation at landslide slopes. Ecol. Eng. 69, 118-125.

Vallauri, D., Aronson, J., Barbero, M., 2002. An analysis of forest restoration 120 years after reforestation on badlands in the Southwestern Alps. Restor. Ecol. 10, 16-26.

Vandaele, K., 2010. From Mudflow Prevention to Ecosystem Services Development, The Melsterbeek catchment, Sint-Truiden, Belgium. The Economics of Ecosystems \& Biodiversity (TEEB). TEEBcase: Changed Agro-management to Prevent Muddy Floods Belgium. Available at:. www.TEEBweb.org.

Verstraeten, G., Poesen, J., Gillijns, K., Govers, G., 2006. The use of riparian vegetated filter strips to reduce river sediment loads: an overestimated control measure? Hydrol. Process. 20, 4259-4267.

Walker, L.R., Velázquez, E., Shiels, A.B., 2009. Applying lessons from ecological succession to the restoration of landslides. Plant Soil 324, 157-168.

Wang, J.H., Lu, X.G., Tian, J.H., 2008. Theory and application technology of riparian wetland. Wetland Science 6, 97-104.

Wilson, C., Yagci, O., Rauch, H., Stoesser, T., 2006. Application of the drag force approach to model the flow-interaction of natural vegetation. Journal of River Basin Management, Band Issue 2, 1-10.

Woolsey, S., Capelli, F., Gonser, T., Hoehn, E., Hostmann, M., Junker, B., Paetzold, A. Roulier, C., Schweizer, S., Tiegs, S.D., Tockner, K., Weber, C., Peter, A., 2007. A strategy to assess river restoration success. Freshw. Biol. 52, 752-769.

Xiao, H., Huang, J., Ma, Q., Wan, J., Li, L., Peng, Q., Rezaeimalek, S., 2017. Experimental study on the soil mixture to promote vegetation for slope protection and landslide prevention. Landslides 14, 287-297.

Yildiz, A., Askarinejad, A., Graf, F., Rickli, C., Springman, S.M., 2015. Effects of roots and mycorrhizal fungi on the stability of slopes. In: Winter, M.G., Smith, D.M., Eldred, P.J.L Toll, D.G. (Eds.), XVI ECSMGE Geotechnical Engineering for Infrastructure and Development. ICE Publishing, pp. 1693-1698.

Yildiz, A., Rickli, C., Graf, F., Springman, S.M., 2018. An Assessment of Plant-induced Suction and Its Effects on the Shear Strength of Root-permeated Soils. Geoderma Submitted in revised form 08 Feb 2018 (GEODER_2017_1623).

Zeh, H., 2007. Soil Bioengineering Construction Type Manual. Verein für Ingenieurbiologie Vdf-EFIB. p. 441. 